\title{
Emblica Officinalis Protects against Sodium Arsenite Induced Hepatotoxicity \& Nephrotoxicity in Rats
}

\author{
Arun Kumar ${ }^{1}$, Raj Bala², Farida Bano², Ranjit Kumar', Mohammad \\ Ali $^{1}$
}

${ }^{1}$ Mahavir Cancer Institute \& Research Centre, Phulwarisharif, Patna (Bihar), India

${ }^{2}$ Department of Zoology, Mahant Maha Devanand Mahila College, Veer Kunwar Singh University, Ara

\begin{abstract}
Arsenic in the present times has caused lots of health hazards to humans. In developing countries like Bangladesh and India the high prevalence of contamination, the isolation and poverty of the rural population, and the high cost and complexity of arsenic removal systems have imposed a programmatic and policy challenge on an unprecedented scale. Although in India, Arsenic poisoning in ground water in Gangetic belt especially the districts adjoining the river Ganges right from Eastern Uttar Pradesh, Bihar to West Bengal are the major problem of concern as due to which major health related problems are arising. To combat the present problem, a pre-clinical study was done on Charles foster rats. They were treated with Sodium arsenite for 8 weeks to make arsenic model and upon these arsenic pretreated rats Emblica officinalis was administered for 4 weeks to study the antidote effects of this plant. The plant not only eliminated the effects of arsenic but also reversed the normal physiological activity in the animal by normalising the activity of liver and kidney. The present study concludes that this novel plant possesses hepato-protective as well as nephron-protective activity against arsenic induced toxicity.
\end{abstract}

Keywords: Sodium Arsenite, Emblica Officinalis, Antidote Effect, Rats

\section{Introduction}

In recent times heavy metals poisoning to humans has created havoc. Heavy metals like arsenic have caused lots of health hazards to human population. It is a naturally occurring metalloid (atomic number 33), located on group $\mathrm{V}$ of the periodic table. Exposure to high levels of arsenic through drinking water has been recognized for many decades in some regions of the world, i.e. China, India, and some countries in Central and South America. A huge population is at risk of cancer and other diseases because of chronic arsenic exposure (NRC, 1999, 2001). Environmental exposure to arsenic can cause a variety of cancers, most commonly non-melanoma skin cancers, and chronic toxicity may manifest as diffuse symptoms not easily recognizable as chronic heavy metal toxicity. General adverse health effects associated with human exposure to arsenicals include cardiovascular diseases, neurologic and neurobehavioral disorders, developmental abnormalities, hearing loss, diabetes, fibrosis of the liver and lung, hematological disorders and blackfoot disease (Abernathy et al., 1999; Tchounwou et al.,
1999 and Sordo et al., 2001. In humans, arsenic is known to cause cancer of the skin (Rossman et al., 2004) lung, bladder, liver and kidney (Kitchin, 2001).

Arsenite is known to bind to cellular sulfhydryl, particularly vicinal ones, accounting for its ability to interfere with energy generation (Aposhian, 1989). Once in the tissues, arsenic exerts its toxic effects through several mechanisms, the most significant of which is, the reversible combination with sulfhydryls groups. Arsenic also inhibits numerous other cellular enzymes, especially those involved in cellular glucose uptake, gluconeogenesis, fatty acid oxidation and product-ion of glutathione through sulfhydryl group binding (Aposhian, 2006).

Medicinal plants as a group comprise approximately 8,000 species and account for around $50 \%$ of all the higher flowering plant species of India. Millions of rural households use medicinal plants in a self-help mode. Over one and a half million practitioners of the Indian System of Medicine in the oral and codified streams use medicinal plants in preventive, 
promotive and curative applications. There are estimated to be over 7,800 manufacturing units in India. In recent years, the growing demand for herbal product has led to a quantum jump in volume of plant materials traded within and across the countries. In recent years, there is a tremendous interest in the possible role of nutrition in prevention of disease. In this context, antioxidants, especially derived from natural sources such as Indian medicinal plants and herbal drugs derived from them, require special attention. Antioxidants neutralize the toxic and 'volatile' free radicals. Antioxidants have many potential applications, especially in relation to human health, both in terms of prevention of disease and therapy (Sies,1996 and Halliwell, 1997).

The pulp of the fruit is smeared on the head to dispel headache and dizziness (Perry, 1980). Emblica officinalis leaves and fruit have been used for fever and inflammatory treatments by rural populations in its growing areas. The earlier study have demonstrated potent anti-microbial (Ahmad et al, 1998), antioxidant (Bhattacharya et al, 1999), adaptogenic (Rege et al, 1999), hepatoprotective (Jeena et al, 1999), anti-tumor (Jose et al, 2001) and anti-ulcerogenic activities (Sairam et al, 2002) in the fruits of Emblica officinalis, leaf extracts have been shown to possesses anti-inflammatory activity (Asmawi et al, 1993; Jhantola-Vormisto et al, 1997).

\section{Materials \& Methods}

Test Chemical: Sodium Arsenite AR (98.0\%), (CAS No.7784-46-5, Lot No. 20/21-28a-45-60-61) manufactured by Loba Chemie, India was obtained from the Scientific store of Patna.

Animals: Charles Foster rats (30 males), weighing $160 \mathrm{~g}$ to $180 \mathrm{~g}$ of 8 weeks old, were obtained from animal house of Mahavir Cancer Institute and Research Centre, Patna, India (CPCSEA Regd-No. 1129/bc/07/CPCSEA). The research work was approved by the IAEC (Institutional Animal Ethics Committee) with IAEC No. IAEC/2012/12/04. Food and water to rats were provided ad libitum (prepared mixed formulated food by the laboratory itself). The experimental animals were housed in conventional polypropylene cages in small groups ( 2 each). The rats were randomly assigned to control and treatment groups. The temperature in the experimental animal room was maintained at $22 \pm 2^{\theta} \mathrm{C}$ with $12 \mathrm{~h}$ light/dark cycle.

Preparation of fruit aqueous extract of Emblica officinalis : In the present study, fresh fruit of Emblica officinalis were purchased from the local market of Patna, Bihar, India. The identity of the medicinal fruit was confirmed by Dr. Ramakant Pandey (Botanist), Department of Biochemistry, Patna University, Patna, Bihar, India. The collected fruit of Emblica officinalis were shade dried and were grinded to fine powder. The aqueous extract dose was calculated after $\mathrm{LD}_{50}$ estimation and finally made to $100 \mathrm{mg} \mathrm{kg}^{-1}$ body weight.

Experimental Design: The animals were grouped into 4 groups. Group 1 was Control group $(n=6)$ to which no treatment was given and was designated as healthy control, while to the rest 3 groups $(n=24)$ Sodium arsenite at the dose of $8 \mathrm{mg} \mathrm{Kg}^{-1}$ body weight was administered orally daily for 6 weeks as well as 8 weeks respectively. Group $2 \& 3$ animals at the end of the Sodium arsenite treatment were dissected for the biochemical assay. Upon these Sodium arsenite pre-treated groups, Emblica officinalis aqueous fruit extract was administered at the dose of $100 \mathrm{mg} \mathrm{Kg}^{-1}$ body weight for 4 weeks. At end of the entire treatment, animals were anaesthetized and dissected and their blood samples were collected and serums were extracted. The serums were then assayed for biochemical study as Liver function tests, Kidney function tests and lipid peroxidation.

Biochemical Evaluation: The Liver Function Test (LFT) as Serum Glutamic Pyruvate Transaminase (SGPT) and Serum Glutamic Oxaloacetate Transaminase (SGOT) were measured according to method (Reitman \& Frankel, 1957), Alkaline Phosphate (ALP) by method (Kind \& King, 1954) while total bilirubin activity by method (Jendrassik \& Grof, 1938). The Kidney Function Test (KFT) were assayed by methods as Urea by (Berthelot, 1859 and Fawcett, 1960), Uric acid by (Bones, 1945) and Creatinine by (Toro et al 1975).

Lipid Peroxidation : Thiobarbituric acid reactive substances (TBARS), as a marker for LPO, were determined by the double heating method (Draper and Hadley, 1992). The principle of the method was a spectrophotometric measurement of the color produced during the reaction to thiobarbituric acid (TBA) with malondialdehyde (MDA). For this purpose, $2.5 \mathrm{ml}$ of $100 \mathrm{~g} / \mathrm{l}$ trichloroacetic acid (TCA) solution was added to $0.5 \mathrm{ml}$ serum in a centrifuge tube and incubated for $15 \mathrm{~min}$ at $90^{\circ} \mathrm{C}$. After cooling in tapwater, the mixture was centrifuged at $3000 \mathrm{~g}$ for $10 \mathrm{~min}$, and $2 \mathrm{ml}$ of the supernatant was added to $1 \mathrm{ml}$ of $6.7 \mathrm{~g} / \mathrm{l} \mathrm{TBA}$ solution in a test tube and again incubated for $15 \mathrm{~min}$ at $90^{\theta} \mathrm{C}$. The solution was then cooled in tap water and its absorbance was measured using Thermo Scientific UV-10 (UV -Vis) spectrophotometer (USA) at $532 \mathrm{~nm}$.

\section{Statistical Analysis}

Results are presented as mean \pm SD and total variation present in a set of data was analysed through one way analysis of variance (ANOVA). Difference among mean values has been analysed by applying Dunnett's test. Calculations were performed 
with the Graph Pad Prism Program (Graph Pad software, Inc., San Diego, U.S.A.). The criterion for statistical significance was set at $P<0.05$.

\section{Results \\ Morbidity and mortality}

The rats after the exposure of arsenic $\left(8 \mathrm{mg} \mathrm{Kg}^{-1}\right.$ body weight per day) for 60 days showed toxicity symptoms such as nausea, nose bleeding, lack of body co-ordination (11 percent of rats showed paralysis like symptoms), blackening of tongue and foot and general body weakness.

\section{Biochemical Changes}

The SGPT, SGOT, alkaline phosphatase, total bilirubin, urea, uric acid, creatinine and lipid peroxidation activity showed significant increase ( $p$ $<0.05)$ in arsenic treated group in comparison to control rat group. But, these values are significantly lowered $(\mathrm{p}<0.05)$ in Emblica officinalis treated group. The biochemical assessment thus shows the hepatoprotective and nephroprotective activity of Emblica officinalis (Graph fig.1-8).

\section{Discussion}

The liver is the primary target organ for the metabolism of arsenicals. The major metabolic pathway of inorganic arsenic in humans is its methylation in the liver. In the present study, the abnormally high levels of serum SGPT, SGOT, ALP and total bilirubin denotes the degree of toxicity in the liver. The significant increase in the levels is a direct measure of hepatic injury and they show the status of the liver as there may be cellular leakage and loss of functional integrity of hepatocytes. Furthermore, there was significant increase in the levels of the lipid peroxidation denotes oxidative stress produced by the arsenic leading to high degree of degeneration in the liver cells. The biochemical cause is the methylation of arsenic in the presence of monomethylarsonic acid (MMA) and dimethylarsinic acid (DMA) in the urine and bile (Sultana et al, 2005; Cui et al, 2004). Monomethylarsonic acid is relatively more genotoxic than the dimethylarsinic (Colognato et al, 2007). Generally the toxicity of arsenic is thought to be largely the result of its reaction with free sulfhydryl groups of enzymes and proteins, followed by cross linkage (Hossain et al, 2000; Akhand et al 2002). Oxidative DNA damage, acquired tolerance to apoptosis, enhanced cell proliferation, altered DNA methylation, genomic instability, and aberrant estrogen signaling have been reported to be involved in the liver toxicity caused by arsenic (Aposhian \& Aposhian, 1989; Rossman, 2003). Hepatic cancer and other hepatic disorders are considered to be the major causes of arsenic-related mortality (Liu et al,1992; Liu et al, 2002; Zhou et al, 2002). In the present study, there was significant amelioration in the levels of the liver function test parameters as well as the lipid peroxidation levels after E.officinalis administration. The hepatoprotective actions of E.officinalis appear to be mediated by its free radical scavenging, antioxidant, anti-inflammatory and modulation of the xenobiotic detoxification process and lipid metabolism (Thilakchand et al 2013, Sharma et al, 2003, (Deokar, 1998, Bhattacharya et al, 2000). Furthermore, it also exhibits hepatoprotective activity due to its continuously membrane stabilizing, antioxidative and CYP 2E1 inhibitory roles (Tasduq et al, 2005; Sultana et al, 2005).

Similarly, in the present study there was significant increase in the levels of Kidney function tests that is urea, uric acid and creatinine levels. Urea is the end product of protein metabolism and after arsenic intoxication gets increased and serum level of urea increases (Aphosian, 1989). Anetor (2002) revealed that production of oxygen free radicals by arsenic induces tubular necrosis which in turn increases tubular permeability, resulting in diffusion and back leak of the filtrate across the tubular basement membrane back into the interstitium and circulation, leading to an apparent decrease in GFR. Under these circumstances, back leak of filtrate results in decreased excretion and increased retention of nitrogenous waste i.e. urea in serum (Klassen, 1996; Verbeke et al., 1996). The serum uric acid concentration is determined largely by the efficiency of renal clearance and rate of purine metabolism (Anetor,2002; Chandra Sekhar et al., 2003; Dioka et al.,2004; Kalia and Flora, 2005). It is moreover formed from guanine and hypoxanthine via xanthinein reactions catalysed by guanase and xanthine oxidase of liver, small intestine and kidney. Arsenic intoxication changes the activity of guanase and xanthine oxidase which results into the increased serum level of uric acid. The increased level of serum creatinine after arsenic intoxication is due to enhanced formation of metabolic waste product of muscle metabolism. Furthermore, creatinine is anhydride of creatinine and muscle contains phosphocreatinine which undergoes spontaneous cyclization with loss of inorganic phosphorous to form creatinine. Due to affinity for thiol group of various proteins found in the cell membrane of muscles, arsenic damages the cells due to which the enzyme CPK (Creatine phosphokinase) gets released from the cells which is responsible for the conversion of phosphocreatinine in to creatinine, thus increases the level of creatinine. In the present study, there was significant amelioration in the levels of the kidney function test parameters levels after E.officinalis administration. E.officinalis shows a strong antioxidant cascade mechanism that is partially due to the presence of ascorbic acid and phenolic compounds (Ghosh et al, 1992; Kumar et al, 2006; 
Rajak et al, 2004). Emblica officinalis ameliorates the arsenic induced nephrotoxicity by reducing the oxidants level in the nephrocytes. The active constituents emblicanin A and B acts as good antioxidant which plays the vital role to eliminate the oxidants from nephrocytes (Chakraborty \& Verma 2010, Ghosal et al; 1996, Scartezzini et al 2010).

Conclusion: Thus, from the entire study, it can be concluded that, Emblica officinalis possesses hepatoprotective as well as nephroprotective effect against arsenic induced toxicity.

\section{Disclosure of interest}

The authors declare that they have no conflicts of interest concerning this article.

Funding: Department of Science and Technology (DST), TDT- SSTP Division, New Delhi, India (Government of India).Research Project No. DST/SSTP/Bihar/155/2011 (G).

\section{Acknowledgements}

The authors extend their appreciation to the Department of Science \& Technology, (SSTP Division) Ministry of Science \& Technology, Government of India, New Delhi for the financial assistance of this work and to the institute for the entire infrastructural facilities.

\section{References:}

I. Abernathy, C.O., Y.P. Liu, D. Longfellow, H.V. Aposhian, B. Beck, B. Fowler, R. Goyer, R. Menzer, T. Rossman, C. Thompson and W. Michael (1999) Arsenic: health effects, mechanisms of actions, and research issues. Environ. Hlth. Perspect., 107, 593-597. http://dx.doi.org/10.1289/ehp.99107593

II. Ahmad, I., Mehmood Z. and Mohammad F. (1998) Screening of some Indian medicinal plants for their antimicrobial properties. J. Ethnopharmacol., 62: 183193. http://dx.doi.org/10.1016/s0378-8741(98)00055-5

III. Akhand AA, Du J, Liu W, Hossain K, Miyata T, Nagase F, Kato M, Suzuki H, Nakashima I (2002) Redox-Linked Cell Surface-Oriented Signaling for TCell Death. Antioxid Redox Signal, 4:445-454. http://dx.doi.org/10.1089/15230860260196236

IV. Anetor, J.I. (2002) Serum uric acid and standardized urinary protein: Reliable bioindicators of lead nephropathy in Nigerian lead workers. African $J$. Biomed. Res., 5, 19-24.

V. Aposhian HV, Aposhian MM (2006) Arsenic Toxicology: Five Questions. Chem Res Toxicol; 19 : 160. http://dx.doi.org/10.1021/tx050106d

VI. Aposhian, H.V. and Aposhian MM (1989).Newer developments in arsenic toxicity J.Am. Coll. Toxicol., ; 8 , 1297-1305. http://dx.doi.org/10.3109/10915818909009121

VII. Asmawi, M.Z., H. Kankaanranta, E. Moilaness and H. Vapaatalo, (1993) Anti-inflammatory activities of Emblica officinalis Gaertn. J. Pharmacol., 45: 581-584. http://dx.doi.org/10.1111/j.2042-7158.1993.tb05605.x

VIII. Berthelot MPE (1859), Report Chim. Appl,; 2884.

IX. Bhattacharya, A., Chatterjee A., Ghosal S. and Bhattacharya S.K., (1999) Antioxidant activity of active tannoid principles of Emblica officinalis (Amla). Indian J. Exp. Biol., 37: 676-680.
X. Bhattacharya, A., S. Ghosal and S.K. Bhattacharya, (2002) Antioxidant activity of tannoid principles of Emblica officinalis (amla) in chronic stress induced changes in rat brain. Indian J Exp Biol., 38(9): 877-80. http://dx.doi.org/10.1078/0944-7113-00090

XI. Bones RW. (1945) J Biol Chem, pp.; 158-581.

XII. Chakraborty D, Verma R (2010) Ameliorative effect of Emblica officinalis aqueous extract on ochratoxininduced lipid peroxidation in the kidney and liver of mice. Int J Occup Med Environ Health 23:63-73. http://dx.doi.org/10.2478/v10001-010-0009-4

XIII. Chandra Sekhar, K., Chary N.S., Kamala C.T., Venkatesware Rao J., Balaram V. and Anjaneya Y. (2003). Risk assessment and pathway study of arsenic in industrially contaminated sites of Hyderabad: A case study. Environ. Int., 29, 601-611. http://dx.doi.org/10.1016/s0160-4120(03)00017-5

XIV. Colognato R, Coppede F, Ponti J, Sabbioni E, Migliore L (2007) Genotoxicity induced by arsenic compounds in peripheral human lymphocytes analysed by cytokinesis-block micronucleus assay. Mutagenesis, 22:255-261. http://dx.doi.org/10.1093/mutage/gem010

XV. Cui X, Kobayashi Y, Hayakawa T, Hirano S (2004) Arsenic speciation in bile and urine following oral and intravenous exposure to inorganic and organic arsenics in rats. Toxicol Sci, 82:478-487. http://dx.doi.org/10.1093/toxsci/kfh265

XVI. Deokar A.B, (1998) Medicinal plant grown at Rajegaon. First ed. D.S Manav vikas foundation Pune,pp-48-49.

XVII. Dioka, C.E., O.E. Orisakwe, F.A. Adeniyi and S.C Meludu (2004). Liver and renal function tests in artisans occupationally exposed to lead in mechanic village in Nnewi, Nigeria. Int. J. Environ. Res. Pub. Hlth., $\quad 1, \quad 21-25$ http://dx.doi.org/10.3390/ijerph2004010021

XVIII. Draper HH, Hadley M. Malondialdehyde determination as index of lipid peroxidation. Methods Enzymol 1990; 186:421- 31. http://dx.doi.org/10.1016/00766879(90)86135-i

XIX. Fawcett JK, Scott JE. (1960) “A rapid and precise method for the determination of urea”. J Clin Pathol, 13(2)156-159. http://dx.doi.org/10.1136/jcp.13.2.156

XX. Ghosal S, Tripathi VK, Chauhan S. (1996) Active constituents of Emblica officinalis. Part I. The chemistry and antioxidative effects of two new hydrolysable tannins, emblicanin A and B. Indian $J$ Chem Sec B:35:941-8. http://dx.doi.org/10.1002/chin.199647279

XXI. Ghosh A, Sharma A, Talukdar G. (1992) Relative protection given by extract of Phyllanthus emblica fruit and an equivalent amount of vitamin $\mathrm{C}$ against a known clastogen- caesium chloride. Food Chem Toxicol;30:865-9. http://dx.doi.org/10.1016/02786915(92)90052-m

XXII. Halliwell, B., (1997) Antioxidants and human diseases: A general introduction. Nutr. Rev., 55: S44-S49. http://dx.doi.org/10.1111/j.1753-4887.1997.tb06100.x

XXIII. Hossain K, Akhand AA, Kato M, Du J, Takeda K, Wu J, Takeuchi K, Liu W, Suzuki H, Nakashima I (2000): Arsenite induces apoptosis of Murine T lymphocytes through membrane raft-linked signaling for activation of cJun amino-terminal kinase. J Immunol 165:42904297. http://dx.doi.org/10.4049/jimmunol.165.8.4290

XXIV. Jeena K.J., Joy K.L, Kuttan R.(1999) Effect of Emblica officinalis, Phyllanthus amarus and Picrorhizia kurroa on N-Nitrosodiethyl amine induced hepatocarcinogenesis. Cancer letter, 136:11-16. http://dx.doi.org/10.1016/s0304-3835(98)00294-8

XXV. Jendrassik L, Grof P, (1938) Vereinfachte. Photometrische Methodenzur Bestimmung des Blubilirubins. Biochem Z ; 297, 81-89.

XXVI. Jhantola-Vormisto A,summanen J.,Kankaanranta H.,Vuorela H., Ashwani Z.M, Moilanen E.,(1997) Anti- 
inflammatory activity of extracts from leaf of Phyllantinus emblica. Plant medica 63, 518-524. http://dx.doi.org/10.1055/s-2006-957754

XXVII. Jose, J.K., G. Kuttan and R. Kuttan, (2001) Antitumour activity of Emblica officinalis. J. Ethnopharmacol., 75: 65-69. http://dx.doi.org/10.1016/s0378-8741(00)003780

XXVIII. Kalia, K. and S.J.S. Flora (2005). Strategies for safe and effective therapeutic measures for chronic arsenic and lead poisoning. J. Occup. Hlth., 47, 11-21. http://dx.doi.org/10.1539/joh.47.1

XXIX. Kind, PRN, King, EJ (1954) Estimation of Plasma Phosphatase by Determination of Hydrolysed Phenol with Amino-antipyrine. J Clin Path; 7(4), 322-326. http://dx.doi.org/10.1136/jcp.7.4.322

XXX. Kitchin KT. (2001) Recent advances in arsenic carcinogenesis: Modes of action, animal model systems, and methylated arsenic metabolites. Toxicol. Appl. Pharmacol. 172:249-261. http://dx.doi.org/10.1006/taap.2001.9157

XXXI. Klassen, C.D. (1996). Heavy metals and heavy metal antagonists. In: Goodman and Gilman's the pharmacological basis of therapeutics (Eds.: J.G. Hardman, A.G. Gilman and L.E. Limbird). McGraw Hill, New York. pp. 1649-1672.

XXXII. Kumar GS, Nayaka H, Dharmesh SM, Salimath PV. (2006) Free and bound phenolic antioxidants in amla (Emblica officinalis) and turmeric (Curcuma longa). Journal of Food Composition and Analysis;19:446-52. http://dx.doi.org/10.1016/j.jfca.2005.12.015

XXXIII. Li X, Pi J, Li B, Xu Y, Jin Y, Sun G (2008) Urinary arsenic speciation and its correlation with 8-0HDG in Chinese residents exposed to arsenic through coal burning. Bull Environ Contam Toxicol, 81:406-411. http://dx.doi.org/10.1007/s00128-008-9471-0

XXXIV. Liu DN, Lu XZ, Li BL, Zhou DX, Li FX, Zheng DH, Wang KH (1992) Clinical analysis of 535 cases of chronic arsenic poisoning from coal burning. Chin $J$ Med, 31:560-562

XXXV. Liu J, Zheng B, Aposhian HV, Zhou Y, Cheng ML, Zhang AH, Waalkes MP (2002) Chronic arsenic poisoning from burning high-arsenic-containing coal in Guizhou, China. Environ Health Perspect, 110:119122. http://dx.doi.org/10.1289/ehp.02110119

XXXVI. NRC (1999) Arsenic in Drinking Water. National Academy Press, Washington, DC.

XXXVII. NRC (2001) Arsenic in Drinking Water. (2001 Update). National Academy Press, Washington, DC.

XXXVIII. Perry, L.M. (1980): Medicinal Plants of East and Southeast Asia: Attributed Properties and Uses, pp. 149 -150. MIT Press, Cambridge. http://dx.doi.org/10.1007/bf02858311

XXXIX. Rajak, S., S.K. Banerjee, S. Sood, A.K. Dinda, Y.K. Gupta, S.K. Guptaand S.K. Maulik, (2004) Emblica officinalis causes myocardial adaptation and protects against oxidative stress in ischemic-reperfusion injury in rats. Phytother Res., 18(1): 54-60. http://dx.doi.org/10.1002/ptr.1367

XL. Rege, N.N., U.M. Thatte and S.A. Dahanukar, (1999) Adaptogenic properties of six rasayana herbs used in Ayurvedic medicine. Phytother. Res., 13: 275-291. http://dx.doi.org/10.1002/(sici)1099-

1573(199906)13:4\%3C275::aid-ptr510\%3E3.0.co;2-s
XLI. Rehaily Al, A.J., Howiriny Al, T.A. Sohaibani Al M.O. and Rafatullah S. (2002) Gastroprotective effects of 'Amla' Emblica officinalis on in vivo test models in rats. Phytomedicine., 9(6): 515-22. http://dx.doi.org/10.1078/09447110260573146

XLII. Reitmann S and Frankel S. (1957) “A colorimetric method for determination of serum glutamate oxalacetic and glutamic pyruvate transaminases." Amer J Clin Path 28(1): 56-63.

XLIII. Rossman TG (2003) Mechanism of arsenic carcinogenesis: An integrated approach. Mutat Res, 533:37-66

http://dx.doi.org/10.1016/j.mrfmmm.2003.07.009

XLIV. Rossman, T.G., A.N. Uddin and F.J. Burns (2004) Evidence that arsenite acts as a cazuocarcinogen in skin cancer. Toxicol. Appl. Pharmacol., 198, 394-404.

XLV. Sairam, K., C.V. Rao, M.D. Babu, K.V. Kumar, V.K. Agrawal and R.K. Goel, (2002) Antiulcerogenic effect of methanolic extract of Emblica officinalis: An experimental study. J. Ethnopharmacol., 82: 1-9. http://dx.doi.org/10.1016/s0378-8741(02)00041-7

XLVI. Scartezzini P, Antognoni F, Raggi MA, Poli F, Sabbiani C. (2006) Vitamin C content and antioxidant activity of the fruit and of the Ayurvedic preparations of Emblica officinalis Gaertn. J Ethnopharmacol;104:113-8.

http://dx.doi.org/10.1016/j.jep.2005.08.065

XLVII. Sharma S.K., Perianyagam J.B.,Joseph A.,Christina A.J.M, (2003) anti-inflammetry activity of ethanol and aqueous extract of Emblica officinalis Gaerth fruits.Hamdard medicus XLVI, 71-73.

XLVIII. Sies H (1986) Biochemistry of Oxidative Stress. Angew Chem Internat Ed Eng; 25,1058-71.

XLIX. Sordo, M., L.A. Herrera, P. Ostrosky-Wegman and E. Rojas (2001) Cytotoxic and genotoxic effects of As, MMA, and DMA on leukocytes and stimulated human lymphocytes. Teratog. Carcinog. Mutagen., 21, 249260. http://dx.doi.org/10.1002/tcm.1013

L. Sultana, S., S. Ahmad, N. Khanand T. Jahangir, 2005. Effect of Emblica officinalis (Gaertn) on $\mathrm{CCl}$ induced 4 hepatic toxicity and DNA synthesis in Wistar rats. Indian J Exp Biol., 43(5): 430-6

LI. Tasduq, S.A., P. Kaisar, D.K. Gupta, B.K. Kapahi, H.S Maheshwari, S. Jyotsna, and R.K. Johri, (2005) Protective effect of a $50 \%$ hydroalcoholic fruit extract of Emblica officinalis against anti-tuberculosis drugs induced liver toxicity. Phytother Res., 19(3): 193-7. http://dx.doi.org/10.1002/ptr.1631

LII. Tchounwou, P.B., B. Wilson and A. Ishaque (1999) Important considerations in the development of public health advisories for arsenic and arsenic containing compounds in drinking water. Rev. Environ. Hlth., 14, 211-229. http://dx.doi.org/10.1515/reveh.1999.14.4.211

LIII. Thilakchand KR, Mathai RT, Simon P, Ravi RT, Rao MPB and Baliga MS, (2013) Hepatoprotective properties of the Indian gooseberry (Emblica officinalis Gaertn): a review Food Funct., 1431-1441. http://dx.doi.org/10.1039/c3fo60237k

LIV. Toro G.\& Ackermann PG. (1975) Practical Clinical Chem; 154

LV. Zhou Y-S, Du H, Cheng M-L, Liu J, Zhang X-J, Xu L (2002) The investigation of death from diseases caused by coal-burning type of arsenic poisoning. Chin $J$ Endemiol 21:484-486. 


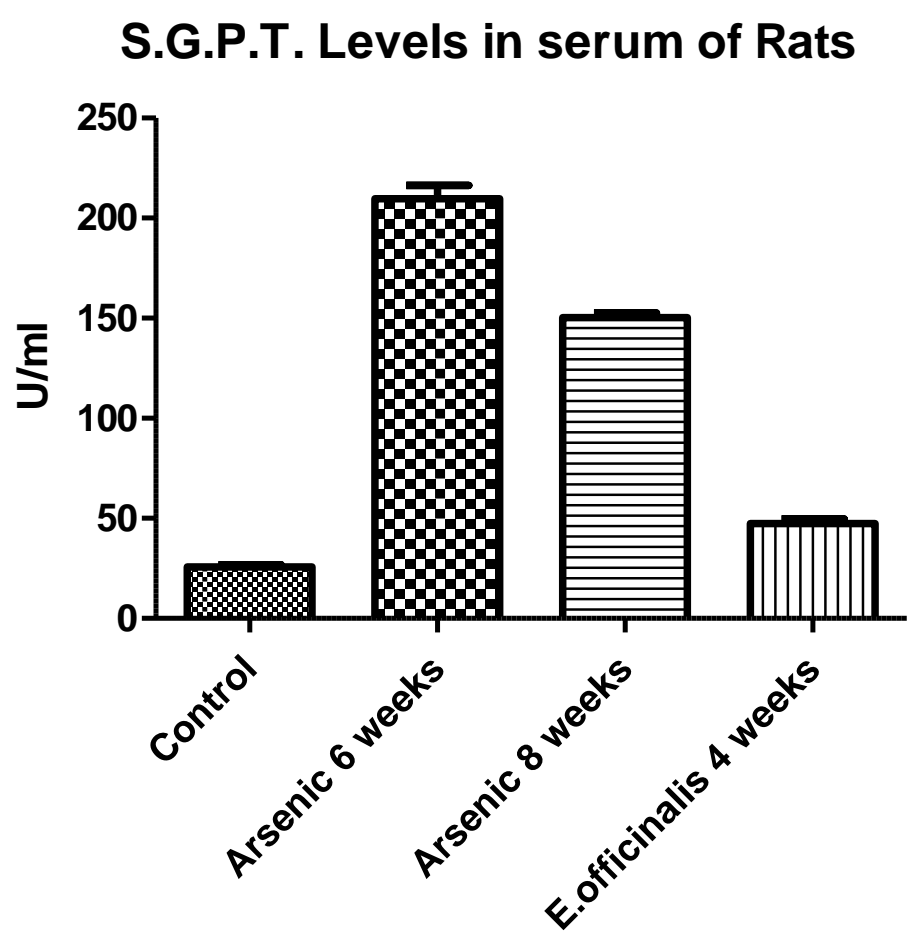

Graph Fig.1: Effect of Emblica officinalis on Arsenic induced toxicity showing SGPT activity (n=6, values are mean \pm S.D)

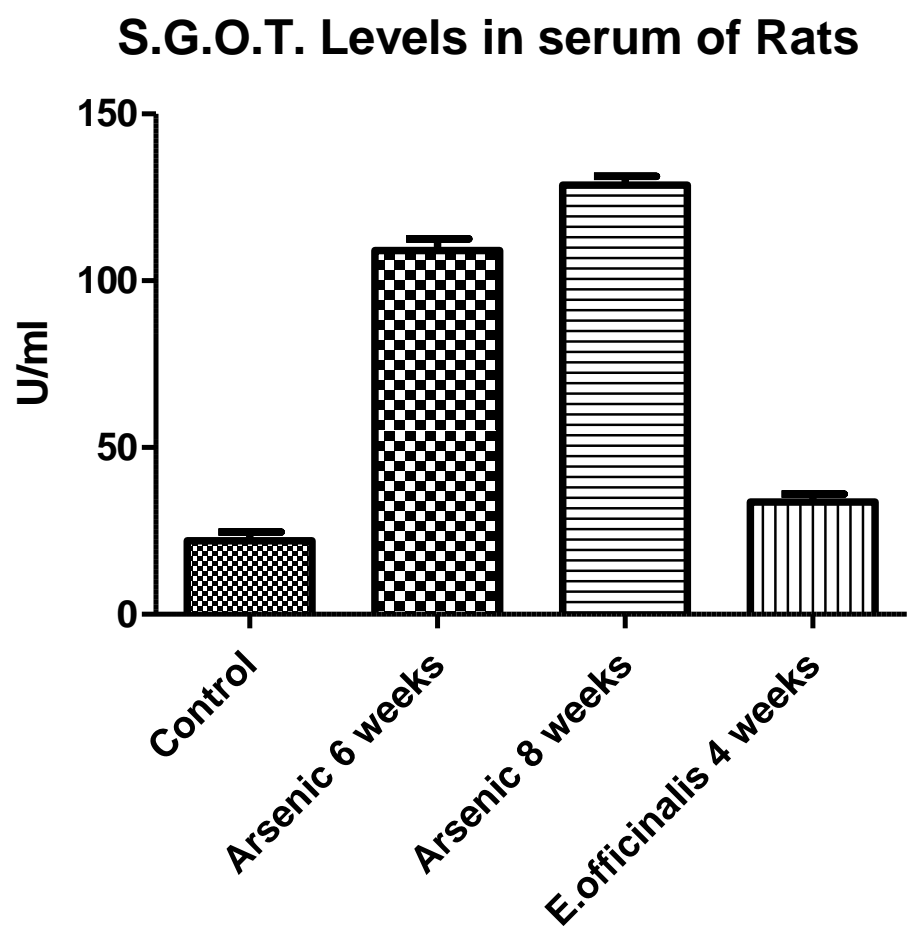

Graph Fig.2: Effect of Emblica officinalis on Arsenic induced toxicity showing SGOT activity (n=6, values are mean \pm S.D) 


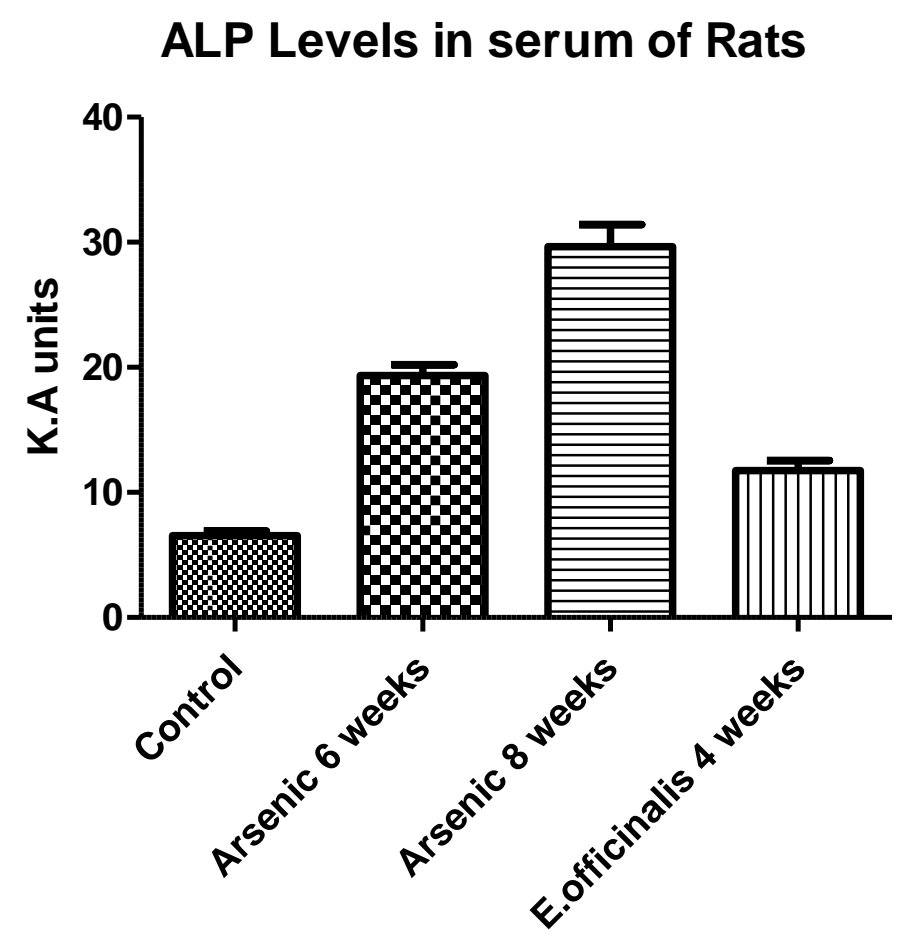

Graph Fig.3: Effect of Emblica officinalis on Arsenic induced toxicity showing Alkaline Phosphatase (ALP) activity $(n=6$, values are mean \pm S.D)

\section{Biluribin Levels in serum of Rats}

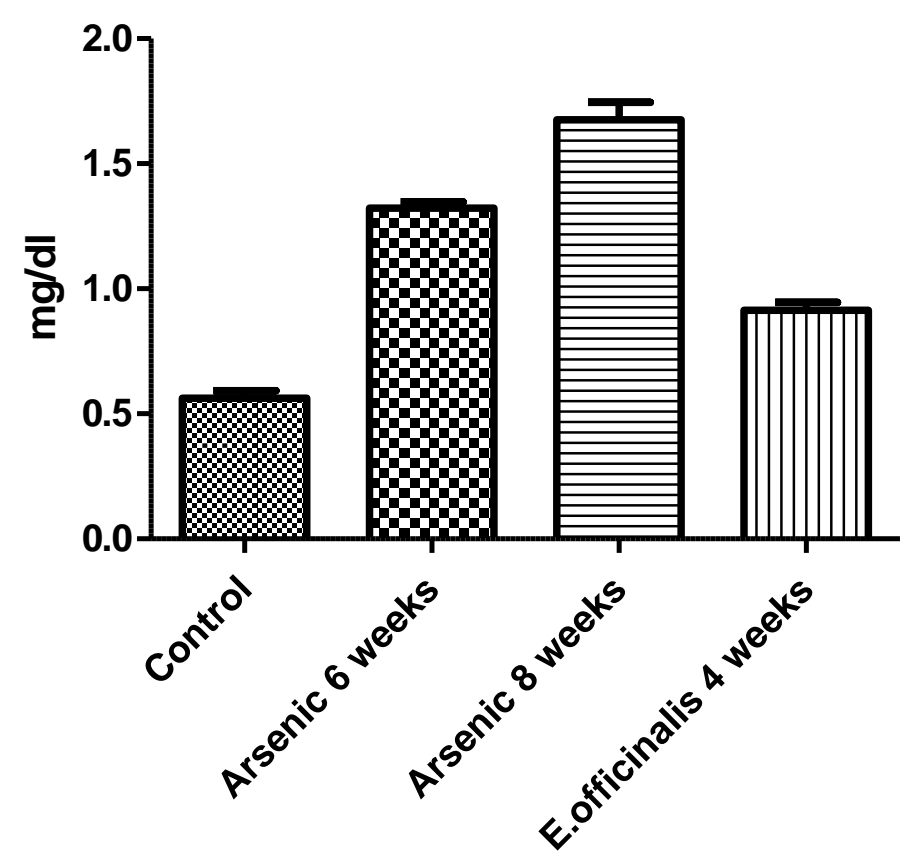

Graph Fig.4: Effect of Emblica officinalis on Arsenic induced toxicity showing bilirubin activity (n=6, values are mean \pm S.D) 


\section{Urea Levels in Serum of Rats}

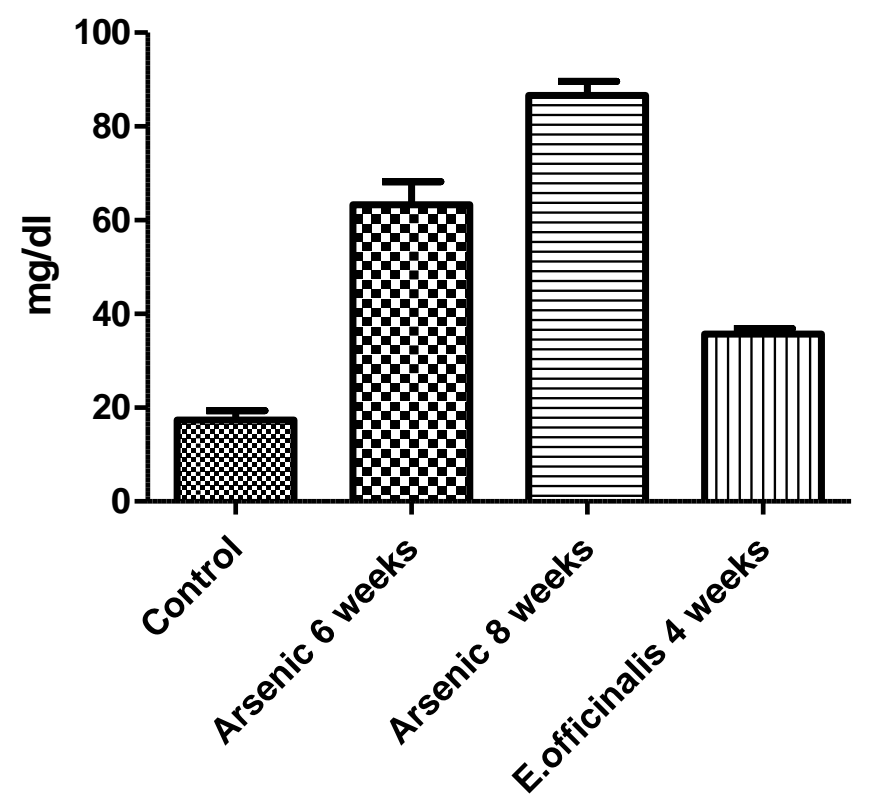

Graph Fig.5: Effect of Emblica officinalis on Arsenic induced toxicity showing serum Urea activity (n=6, values are mean \pm S.D)

\section{Uric acid Levels in serum of Rats}

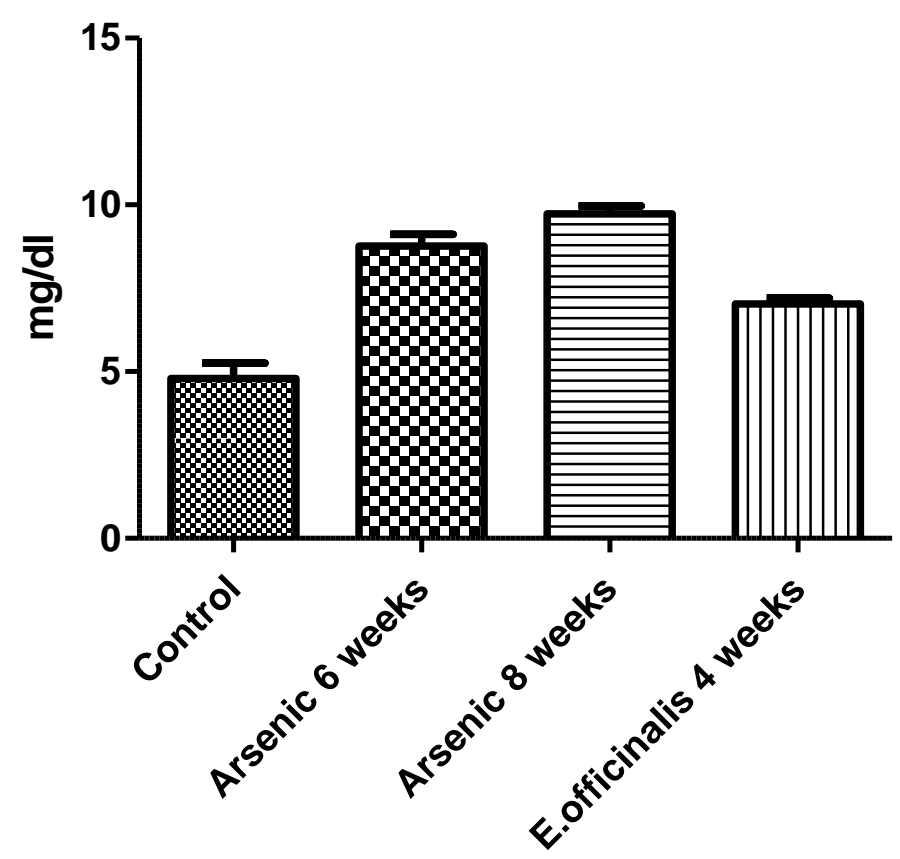

Graph Fig.6: Effect of Emblica officinalis on Arsenic induced toxicity showing serum Uric acid activity (n=6, values are mean \pm S.D) 


\section{Creatinine Levels in serum of Rats}

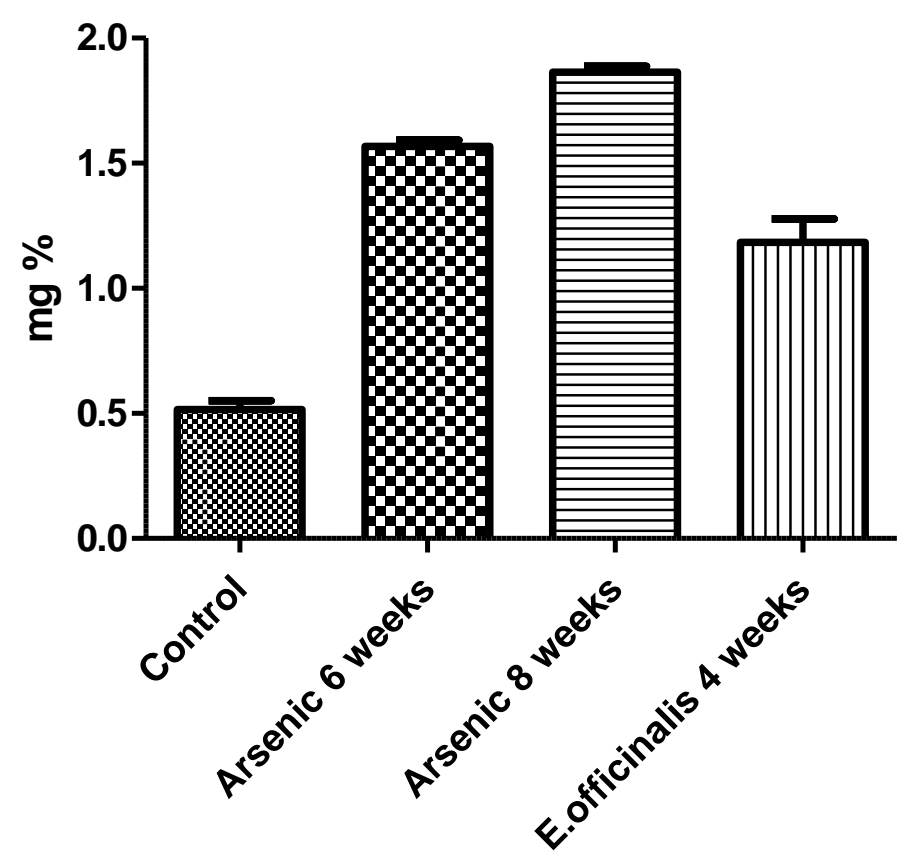

Graph Fig.7: Effect of Emblica officinalis on Arsenic induced toxicity showing serum Creatinine activity $(n=6$, values are mean \pm S.D)

\section{MDA Levels in serum of Rats}

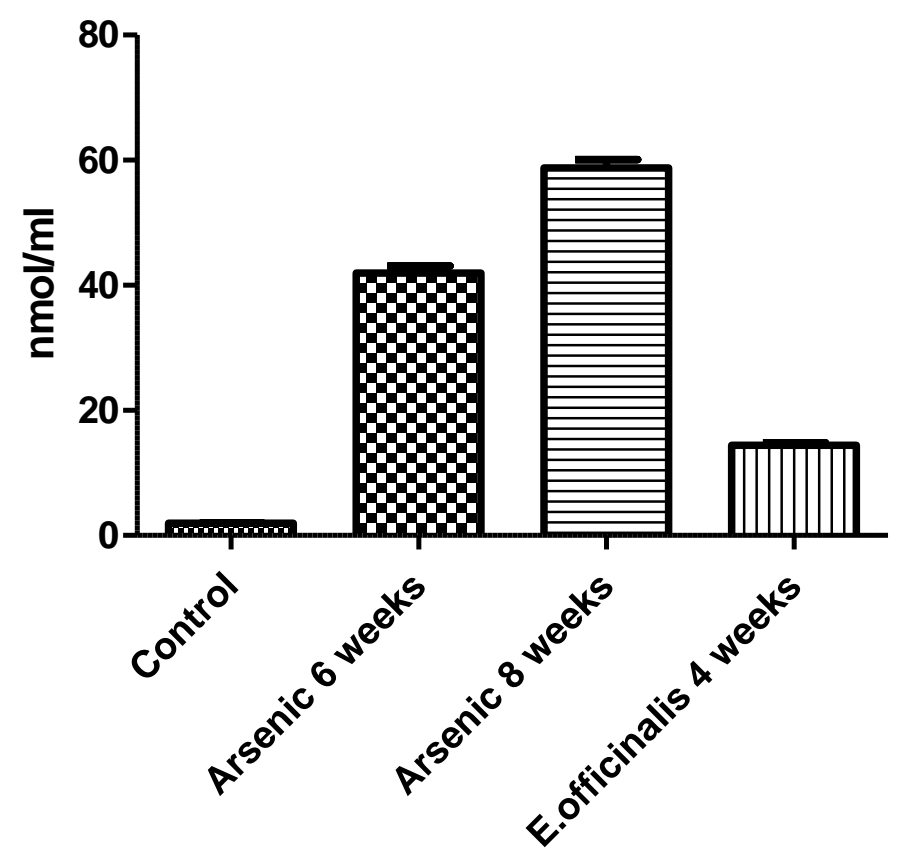

Graph Fig.8: Effect of Emblica officinalis on Arsenic induced toxicity showing serum lipid peroxidation activity $(n=6$, values are mean \pm S.D) 